УДК 342.95:615 (477)

DOI https://doi.org/10.32837/pyuv.v0i2(31).578

В. I. Теремецький

orcid.org/0000-0002-2667-5167

доктор юридичних наук, доцент,

професор кафедри цивільного права і процесу

Тернопільського національного еконолічного університету

O. C. Ховпун

orcid.org/0000-0002-5753-966X

кандидат юридичних наук, доцент,

завідувач кафедри кримінального права, процесу та криміналістики

Академї праці, соціальних відносин і туризму

\title{
СУЧАСНІ ПОНЯТІЙНІ ІНТЕРПРЕТАЦІЇ ТЕРМІНА «ФАРМАЦІЯ» ЯК АДМІНІСТРАТИВНО-ПРАВОВОÏ КАТЕГОРІї
}

Постановка проблеми. Проблематика правового регулювання фармацевтичних відносин набула особливої актуальності внаслідок пандемії COVID-19. Так, 12 травня 2020 р. Рада ЄC провела обговорення Фармацевтичної стратегії для Європи («PSE»), зокрема їі дорожньої карти, з метою подолання нерівного доступу до ліків, визначення міжнародного впливу на фармацевтичну галузь [1]. В Україні ці питання обговорювали при розробці та затвердженні постанови Кабінету Мiністрів України «Про затвердження Державної стратегії реалізації державної політики забезпечення населення лікарськими засобами на період до 2025 р.» від 5 грудня 2018 р. № 1022 [2]. Наведене вказує на актуальність дослідження наукових питань у сфері фармації, які безпосередньо пов'язані не лише з розвитком сегмента економіки держави, державним управлінням фармацевтичної галузі, а й із фундаментальним правом людини на життя й охорону здоров'я.

Аналіз останніх досліджень і публікацій. Незважаючи на наукові суперечки з питань правової охорони фармації, в царині юридичної науки все ще залишаються невизначеними питання категоріального апарату, зокрема точаться дискусії щодо розуміння терміна «фармація». Саме цій проблематиці присвячена стаття Є.Г. Книш та О.Г. Алексєєва «Напрями удосконалення термінологічних підходів до визначення «рармацевтична сфера» у контексті юридичної відповідальності учасників правовідносин, що виникають під час обігу лікарських засобів» (2013) [3]. Автори цієї статті розмежували поняття «фармацевтична сфера» та «фармацевтична галузь», однак без їх співвідношення з більш загальною категорією «фармація». О.Г. Алексєєв в окремій статті «Аналіз та співвідношення термінів «рармацевтична галузь» i «фармацевтична сфера» як об'єктів адміністративно-правової охорони» здійснює аналіз таких базових понять, як «фармацевтична сфе- ра», «фармацевтична галузь» $\mathrm{i}$ «фармацевтична діяльність» (2010) [4]. Намаганню визначити правову конструкцію терміна «фармацевтична діяльність» присвячена робота О.Г. Паровишник «До питання правового регулювання фармацевтичної діяльності в Україні» (2018) [5]. У галузі фармацевтичної науки ця проблематика розглядалася I.M. Перцевим і О.А. Рубан «Стан фармацевтичної термінології та правомірність статусу терміна «фармацевтичний препарат» (2011) [6]. Отже, викладене підкреслює що науковий інтерес до фармацевтичної термінології існує. Єдиного підходу до розуміння терміна «фармація» в аспекті їі адміністративно-правого забезпечення й досі не склалося. Тому тематика категоріальної інтерпретації терміна «фармація» як адміністративно-правової категорії є актуальною і потребує свого наукового розв'язання.

Метою статті є визначення понятійної інтерпретації терміна «фармація» як адміністративно-правової категорії. Для досягнення мети необхідно вирішити такі завдання: охарактеризувати сучасні інтерпретації терміна «фармація», які склалися у фармацевтичній і юридичній науках, розкрити зміст терміна «фармація» як адміністративно-правової категорії, а також сформулювати доцільність використання цього терміна в подальших наукових дослідженнях.

Виклад основного матеріалу. На необхідність термінологічного визначення у праві справедливо звертає увагу В.К. Антошкіна. Вчена зауважує, що існує потенційна конфліктогенність мовних творів, особливо у праві, яка може спричинити серйозні наслідки - аж до порушення прав і законних інтересів суб'єктів правовідносин; саме тому питання тлумачення у праві ніколи не втрачають своєї актуальності [7, с. 14]. 3 такою думкою слід погодитися, оскільки невизначеність у праві містить потенційний конфлікт і призводить до різних, насамперед доктринальних тлу- 
мачень будь-якої правової категорії. Кожен термін - це результат системних (фахових) знань і науково-практичного розуміння, що розкривається у змістовій характеристиці - дефініції (лат. definition - визначення), яка стисло, але точно описує (визначає) суттєві ознаки певного поняття, позначеного терміном [8, с. 12]. Щодо терміна «фармація», то складність його розуміння полягає в тому, що в Законах України «Про лікарські засоби» [9] й «Основи законодавства України про охорону здоров'я» [10] не міститься його визначення. Водночас фармацевтичну термінологію доцільно визначати не тільки як інформацію про відповідний фармацевтичний феномен, a i як юридичну засаду для прийняття рішень та організацію адміністративно-правового забезпечення [6, с. 18]. Тому встановлення повного тлумачення відповідної категорії має особливе значення для системного дослідження у відповідній галузі науки.

Внаслідок того, що будь-яка юридична термінологія базується на знаннях відповідної фундаментальної науки, виникає потреба первинного аналізу понятійних засад, зокрема наукових поглядів на поняття "фармація», розроблених у фармацевтичній науці. Саме первинність у дослідженні фундаментальних наукових понять є гарантією отримання науково виважених юридичних термінів, що об'єктивують реальні явища.

Фармація (грец. pharmakon < лат. pharma ліки; англ. Pharmacy) є комплексним поняттям, що охоплює різні феномені дійсності. До неї належать: 1) науково-практична господарська діяльність із пошуку, синтезу активних і допоміжних речовин, створення, вивчення фармакологічної дії, виробництво ліків за промислових і аптечних умов; 2) науково-практичні напрями (освітнього, наукового, виробничого та соціально-правового характеру) стосовно ліків [11, с. 395]. Поряд із цим терміном виокремлюють поняття «фармацевтична галузь - сукупність підприємств, організацій, установ або їх об’єднань, зайнятих у процесі створення, виробництва фармацевтичної продукції, забезпечення її контролю якості та реалізації, яка характеризується також спільністю технічної або технологічної бази, особливим складом фахівців і специфічністю умов їхньої роботи, освітньої підготовки та перепідготовки кадрів» [6, с. 20]. Як зазначається у наукових фармацевтичних джерелах, поняття «фармацевтична діяльність» співвідноситься із науково-практичною діяльністю у системі охорони здоров'я [10, с. 13]. Аналізуючи положення фармацевтичної науки щодо термінології, слід звернути увагу на різну інтерпретацію таких понять, як «фармація», «фармацевтична галузь», «фармацевтична діяльність» . Категорія «фармація» є базовою, що охоплює як фармацевтичну діяльність, так і усі напрями діяльності людини, пов'язані з лікарськими засо- бами. Фармація повністю охоплює увесь ланцюг фармацевтичної діяльності - від розробки ліків до ïх доведення (реалізації) кінцевому споживачу.

У юридичній літературі існують такі погляди на фармацевтичну термінологію. О.Г. Алексєєв вказує, що фармація є складовою частиною соціально-економічної галузі охорони здоров'я. Вчений надає перевагу терміну «фармацевтична сфера», який охоплює і фармацевтичну діяльність, оскільки включає в себе як виробничі, промислові, так i соціальні аспекти [3, с. 110; 4, с. 40]. Вважаємо, що таке тлумачення терміна «фармація» змінює усталений підхід до його розуміння на більш звужений, який передбачає використання додаткового компонента словосполучення (залежного слова) «у сфеpi», лінгвістичне тлумачення котрого передбачає «межу поширення чого-небудь» $[12$, с. 876]. Тобто фармація є широкою, комплексною категорією, що може застосовуватися у сфері приватного та публічного права й означає всі напрями людської діяльності, пов'язані з лікарськими засобами. У структурі фармації можуть виокремлюватися самостійні сфери цієї діяльності. Також зауважимо, що розглядати фармацію як складову частину соціально-економічної галузі охорони здоров'я не зовсім правильно, адже фармація може бути як частиною соціально-економічної галузі охорони здоров'я, так і самостійним сегментом соціально-економічного сектору держави.

С.В. Васильєв визначає, що різновидами фармацевтичної діяльності є: виготовлення лікарських засобів, промислове виробництво лікарських засобів, виробництво лікарських засобів в умовах аптеки, дистрибуція лікарських засобів, тобто ввезення імпортних лікарських засобів в Україну та вивезення лікарських засобів з території України, оптова та роздрібна торгівля лікарськими засобами [13, с. 17]. Це широкий підхід до визначення фармацевтичної діяльності, що співвідноситься з фармацевтичним ланцюгом. Вчений не співвідносить фармацевтичну діяльність із базовим терміном «фармація».

Н.С. Клунко у дослідженні механізму державного управління фармацевтичного сектору використовує термін «фармація» та підкреслює, що «основою процесу управління фармацією $є$ інформація про елементи фармацевтичної системи» [14, с. 251]. Отже, дослідниця виділяє такі категорії: «фармацевтичний сектор», «фармацевтична система», «фармація». Їхні термінологічні визначення не відображені (сформульовані) у науковій праці автора, що, безумовно, загострило наукову дискусію в питанні визначеності категоріального апарату.

Проблематиці співвідношення фармацевтичної діяльності та фармацевтичної галузі присвячена праця О.В. Паровишник, у якій фармацевтична діяльність визначається як науково-практична 
діяльність у фармацевтичній галузі, з охопленням всього фармацевтичного ланцюга [5, с. 70]. Зауважимо, що науковці при визначенні терміна «фармацевтична діяльність» звертаються до ст. 74 Закону України «Основи законодавства України про охорону здоров' я", згідно з якою фармацевтичною діяльністю можуть займатися особи, котрі мають відповідну спеціальну освіту і відповідають єдиним кваліфікаційним вимогам [9]. Однак ця стаття не закріплює поняття фармацевтичної діяльності, а лише вказує на одну із їі системних ознак.

Узагальнюючи наведене, зауважимо, що для встановлення характерних ознак адміністративно-правового забезпечення фармації спочатку необхідно визначити категоріальний апарат 3 урахуванням конкуренції термінів «фармація», «фармацевтична сфера», «фармацевтична діяльність». Вважаємо, що найбільш базовим терміном $€$ «фармація», що охоплює всі напрями діяльності людини, пов'язані з лікарськими засобами, зокрема державне управління фармацевтичною діяльністю, фармацевтичну науку, підготовку фармацевтичних працівників, управління фармацевтичним підприємством, господарську фармацевтичну діяльність. Крім того, фармацевтична сфера є самостійною частиною фармації, а фармацевтична діяльність - науково-практичною господарською діяльністю, що охоплює фармацевтичний ланцюг. Під останнім слід розуміти систему дій від розробки до реалізації лікарських засобів, включаючи маркетингові дослідження для встановлення потреби на ринку лікарських препаратів; інноваційні розробки нових ліків; контроль якості лікарських препаратів; проведення клінічних досліджень нових лікарських препаратів; реєстрацію нових лікарських препаратів; фармацевтичну логістику; реалізацію лікарських препаратів; фармацевтичний маркетинг; управління фармацевтичним підприємством і підготовку фармацевтичних кадрів. Наведений підхід може використовуватися у подальших наукових дослідженнях у галузі адміністративного права, адже надає можливість найбільш об'єктивно виявити усі елементи цих категорій.

Висновки 3 дослідження і перспективи подальших розвідок у цьому напрямі. На підставі проведеного дослідження можна запропонувати такі висновки. Сучасні інтерпретації терміна «фармація», які існують у фармацевтичній і юридичній науках, мають комплексний характер, оскільки охоплюють публічні та приватно-правові характеристики цього феномену. Для галузі адміністративного права базовим терміном $е$ «фармація», що охоплює всі напрями діяльності людини, пов'язані з лікарськими засобами, зокрема державне управління фармацевтичною діяльністю, фармацевтичну науку, підготовку фармацевтичних працівників, управління фармацевтичним підприєм- ством, господарську фармацевтичну діяльність. Внаслідок того, що формулювання чіткої юридичної термінології є запорукою повного й об'єктивного дослідження, фармацевтична термінологія повинна стати предметом подальших наукових досліджень.

\section{Jimepamypa}

1. Андрощук Г. Фармацевтична стратегія для Європи. Юридична газета. 18.05.2020. URL: https://yur-gazeta.com/publications/practice/ medichne-pravo-farmacevtika/farmacevtichnastrategiya-dlya-evropi.html(датазвернення: 02.06.2020).

2. Про затвердження Державної стратегії реалізації державної політики забезпечення населення лікарськими засобами на період до 2025 р. : постанова Кабінету Міністрів України від 05 грудня 2018 р. № 1022. URL: https://zakon.rada.gov.ua/laws/show/1022-2018$\%$ D0\% BF\#Text (дата звернення: 02.06.2020).

3. Книш Є.Г., Алексєєв О.Г. Напрями удосконалення термінологічних підходів до визначення підходів до визначення "фармацевтична сфера» у контексті юридичної відповідальності учасників правовідносин, що виникають під час обігу лікарських засобів. Запорожский медицинский журнал. 2013. № 5. С. 109-111.

4. Алексєєв О.Г. Аналіз та співвідношення термінів «фармацевтична галузь» та «фармацевтична сфера» як об'єктів адміністративно-правової охорони. Адвокат. 2010. № 8. С. 39-42.

5. Паровишник О.Г. До питання правового регулювання фармацевтичної діяльності в Україні. Науковий вісник Ужгородського національного університету. Серія Право. 2018. Вип. 49. Т. 2. С. 69-72.

6. Перцев I.M., Рубан O.M. Стан фармацевтичної термінології та правомірність статусу терміну «фармацевтичний препарат». Фармацевтичний журнал. 2011. № 4. C. 18-23.

7. Антошкіна В.К. Сутність і підходи до тлумачення права у роботах вітчизняних вчених. Вісник ХНУВС. 2019. № 4(87). С. 13-22.

8. Черних В.П., Перцев I.М. Упорядкування та значення термінології у фармацевтичній діяльності. Еженедельник «Аптека». 2011. № 47 (818). С. 12-13.

9. Про лікарські засоби : Закон України від 04 квітня 1996 p. № 123/96-BP. URL: https://zakon.rada.gov. ua/laws/show $/ 123 / 96-\%$ D0\% B2\% D1\% 80 (дата звернення: 02.06.2020).

10. Основи законодавства України про охорону здоров’я : Закон України від 19 листопада 1992 р. № 2801XII. URL: https://zakon.rada.gov.ua/laws/show/280112 (дата звернення: 02.06.2020).

11. Українська фармацевтична енциклопедія: 1921-1995 / В.П. Черних, I.А. Зупанець, 3.М. Мнушко та ін. ; за ред. В.П. Черних. Харків : Основа, $1996.464 \mathrm{c}$.

12. Словник української мови : в 11 т. / АН УРСР. Інститут мовознавства ; за ред. І.К. Білодіда. Київ : Наукова думка. Т. 9. 1978. 916 с.

13. Васильєв С.В. Законодавче закріплення поняття «фармацевтична діяльність» як передумова підвищення ефективності державного управління у сфері обігу лікарських засобів. Вісник Харківського національного університету внутрішніх справ. 2011. № 4. C. 14-20.

14. Клунко Н.С. Механізм державного управління фармацевтичним сектором України. Теорія та практика державного управління. 2012. Вип. 3. C. $245-251$. 


\section{Анотація}

Теремеиький В. I., Ховпун О. С. Сучасні понятійні інтерпретації терміна "фармація" як адміністративно-правової категорії. - Стаття.

У статті розглянуто категоріальні інтерпретаціі терміна «фармація» в аспекті ї̈ адміністративно-правового забезпечення. Мета статті полягає у визначенні понятійної інтерпретації терміна «фармація» як адміністративно-правової категорії. Необхідність дослідження терміна «фармація» зумовлена відсутністю його тлумачення у Законах України «Про лікарські засоби», «Основи законодавства України про охорону здоров'я», а також неоднаковим розумінням у юридичній і фармацевтичній науках.

Встановлено наявність конкуренції таких термінів, як «фармація», «фармацевтична сфера», «фармацевтична діяльність». У зв'язку з цим сформульована авторська позиція щодо цих понять. Підкреслено, що найбільш базовим терміном є «фармація», який охоплює всі напрями діяльності людини, пов'язані з лікарськими засобами, зокрема державне управління фармацевтичною діяльністю, фармацевтичну науку, підготовку фармацевтичних працівників, управління фармацевтичним підприємством, господарську фармацевтичну діяльність. Наголошено, що фармацевтична сфера - це самостійна частина фармації, фармацевтична діяльність - науково-практична господарська діяльність, яка охоплює фармацевтичний ланцюг. Під останнім розуміється система дій від розробки до реалізації лікарських засобів, включаючи маркетингові дослідження для встановлення потреби на ринку лікарських препаратів, інноваційні розробки нових ліків, контроль їхньої якості, проведення клінічних досліджень нових ліків, їх реєстрація, фармацевтична логістика, реалізація лікарських засобів, фармацевтичний маркетинг, управління фармацевтичним підприємством і підготовка фармацевтичних кадрів. Наведений підхід може використовуватися у подальших наукових дослідженнях у галузі адміністративного права, адже надає можливість найбільш об'єктивно виявити різні аспекти терміна «фармація».

Ключові слова: фармація, фармацевтична сфера, фармацевтична діяльність, фармацевтичний ланцюг, адміністративно-правове забезпечення, управління.

\section{Summary}

Teremetskyi V.I., Khovpun O. S. Modern conceptual interpretations of the term of "Pharmacia" as administrative and legal category. - Article.

The author of the article has studied categorical interpretations of the notion of "pharmacia" in terms of its administrative and legal provision. The purpose of the article is to define the conceptual interpretation of the term of "pharmacia" as an administrative and legal category. The need to study the term of "pharmacia" is due to the lack of interpretation in the Laws of Ukraine "On Medicinal Products", "Fundamentals of the Legislation of Ukraine on Health Care", as well as due to different understanding in legal and pharmaceutical sciences.

The existence of competition of such terms as "pharmacia", "pharmaceutical sphere", "pharmaceutical activity" has been established. In this regard, the author has formulated own position on these concepts. It has been emphasized that "pharmacia" is the most basic term, which covers all areas of human activity related to medicinal products, in particular public administration of pharmaceutical activities, pharmaceutical science, training of pharmaceutical employees, management of pharmaceutical companies, economic pharmaceutical activities. It has been emphasized that the pharmaceutical sphere is an independent part of pharmacia; pharmaceutical activity is scientific and practical economic activity that covers the pharmaceutical chain. The latter means the system of actions from development to sale of medicinal products, including marketing research in order to determine the need at the market of medicinal products, innovative development of new drugs, their quality control, clinical trials of new drugs, their registration, pharmaceutical logistics, medicinal products' sales, pharmaceutical marketing, management of pharmaceutical companies and training of pharmaceutical personnel. This approach can be used in further research in the field of administrative law, as it provides an opportunity to most objectively identify various aspects of the term of "pharmacia".

Key words: pharmacia, pharmaceutical sphere, pharmaceutical activity, pharmaceutical chain, administrative and legal prvision, management. 